\title{
COOPETITION STRATEGY IN THE DEVELOPMENT OF AGROTOURISM BUSINESS ENTITIES
}

\author{
Edyta GĄSIOROWSKA-MĄCZNIK \\ Politechnika Świętokrzyska, Kielce; edytag@tu.kielce.pl, ORCID: 0000-0002-9224-3389
}

\begin{abstract}
Purpose: The main study objective is to identify the most important reasons why owners of agrotourism business entities undertake coopetition activities and to identify the benefits and risks resulting from the implementation of the coopetition strategy.

Project/methodologyapproach: Theoretical aspects of the coopetition strategy are the starting point for pilot studies carried out in the Świętokrzyskie region on a sample of 150 agrotourism business entities, which accounts for about $30 \%$ of all such entities operating in the region. An interview questionnaire was used in the study. A deliberate selection of the research area and the subjects surveyed was assumed.

Results: The analysis of the results of the pilot study shows that the coopetition strategy brings greater benefits to agrotourism business entities than competition and co-operation strategies implemented separately, the benefits include: expanding the scale of operations, strengthening the position of the company in relation to competitors which are not parties to the coopetition agreement, and access to new customer markets. When making a decision on cooperation, the surveyed owners of agrotourism business entities most often treat it as a strategic decision, i.e. relating to effects in a distant time horizon, and its main reason is to increase competitiveness on the market.
\end{abstract}

Practical implications: Both cooperation and competition relations are important for the development of agrotourism business entities. Cooperative relationships are created as associations, usually to carry out tasks aimed at increasing the attractiveness of a given tourist destination. Competitive relationships concern in particular the individual offer of services, their quality and diversity. The consequences of both types of activities have a significant impact on building competitive advantage of the surveyed business entities.

Originality/value: The analysis of literature leads to the conclusion that there are no scientific studies showing the coopetition in relation to the activities of agrotourism business entities. Therefore, the issues addressed form a research gap. The article is directed to owners of agrotourism business entities and agrotourism associations.

Keywords: coopetition, agrotourism business entities, Świętokrzyskie voivodeship.

Category of the paper: research paper. 


\section{Introduction}

Organizations that are in a cooperative and competitive relationship pursue a coopetition strategy. Coopetition is an arrangement of simultaneously being in a cooperative and competitive relationship between competitors who retain their organizational individuality. It is a system of interaction based on partial compliance of interests and objectives. It is a relationship that combines cooperation in a certain range of activities with competition in other areas of activity. Such an understanding of coopetition creates the basis for separating coopetition as a strategy and for distinguishing it from competition and cooperation. Agrotourism business entities can be a good example of how a coopetition strategy can be implemented for at least two reasons. Firstly, they cooperate under various types of organizations, e.g. agrotourism associations. Joint action has the potential to generate benefits, including access to resources, reduced transaction costs, better coordination and increased innovativeness. The cooperation facilitates the promotion of services, exchange of experience, maintenance of folklore, cultural and culinary traditions of the region. Cooperative relations are usually created to achieve specific objectives, within a specific time horizon and their consequences have a significant impact on the development strategy of the entities involved. Secondly, agrotourism entities compete for customers. By extending and diversifying the offer of farms, improving the quality and diversity of services, improving the aesthetics of the homestead, they become more competitive in a given area. Agrotourism entities build and maintain their competitive advantage, based on cooperation and competition.

\section{Theoretical perspective on the coopetition strategy}

The term "coopetition" was first used in 1993 by the founder and CEO of Novell, Raymond Noord (Brandenburger, and Nalebuff, 1996). This term was supposed to mean simultaneous competition and cooperation between two or more business partners, assuming that there are repetitive interactions. Classical competition makes it necessary to knock a rival out of the game or restrict his access to the market. Coopetition, on the other hand, means that competition can be treated as a more profitable game for all participants. Such a game is aimed at maximizing the generated value and then competing for the highest possible share in it (Czakon, 2009).

From the perspective of research on coopetition conducted in Polish scientific centers, the achievements of W. Czakon, J. Cygler and B. Jankowska (Czakon, 2009; Czakon, 2005; Cygler, and Romanowska; 2014, Jankowska, 2009) deserve special attention. The contribution of these authors to the development of the discussed issues is undeniable. It should be noted that the majority of Polish mainstream researchers consider coopetition to be a domain of 
strategic management (Czakon, 2005; Cygler, and Romanowska, 2014). Coopetition is associated with key elements for strategic management, such as strategic objectives. Its origin is proven on the basis of the resource-based view strategy (Jankowska, 2009; Stańczyk-Hugiet, 2011), and it is identified with the strategy itself. In this sense, coopetition may constitute a repetitive, observable pattern of behavior, regardless of whether it was previously planned, agreed or emerged spontaneously (Czakon, 2009). Despite the diversity of methods used in the research on coopetition, as well as the significant diversity of fields and areas with which it is associated, it is possible to identify its properties that make it possible to conclude that it is universal. First of them, shown chronologically the earliest, is the simultaneity of occurrence of competitive and cooperative behaviors as the basic inter-organizational relations. The second characteristic of a coopetition is mutual benefit or added value for the entities participating in the coopetition (coopetitors).

The distinguishing features of coopetition include:

- duality of existing relations - simultaneous occurrence of competition and cooperation relations, which is possible thanks to the separation of areas for individual activities, as well as effective coordination of activities in these separated zones of functioning of the cooperating organizations;

- interdependence - is manifested by the mutual dependence of the parties involved, as well as by the sharing of resources that have been contributed to cooperation in the form of an in-kind contribution, which can take any form (material, competence or skills);

- longevity of relations - the longer the horizon of cooperation, the more willingly cooperation relations are undertaken; longer time of cooperation also influences the number and diversity of agreements undertaken within the framework of coopetition and its internal structure;

- openness - two organizations at least must cooperate, but there is no limit for the number of parties involved; openness also applies to markets that participate in the coopetition, since the cooperating parties do not have to be only direct competitors; forms and scope of cooperation may also be arbitrary - the decisive factor in this case is only the will of the parties and the possibility of achieving jointly defined goals.

Coopetition as a form of cooperation enables companies and other market entities to achieve a competitive advantage through specific resources, competencies and a specific market position, while attempting to integrate their strengths with those of competitors, suppliers, customers and other economic partners (Jankowska, 2009). This cooperation is built on a formal or informal division of tasks, activities and resources.

In line with the paradigm of cooperation, companies are convinced that they can improve their performance by combining complementary resources, skills and capabilities. For this purpose, they choose forms of cooperation that help them to achieve a competitive advantage. According to K. Romaniuk (Romaniuk, 2012), instead of looking for ways to gain an advantage 
over rivals, companies should focus on obtaining common benefits by establishing and maintaining mutual relations. The implementation of such a perspective is to achieve advantage through alliances and networks, i.e. through coopetition. M. Bengtsson and S. Kock also noticed the need for companies to reach for new concepts increasing the chances of gaining a competitive advantage. According to these authors (Bengtsson, and Kock, 2000), there are three forms of coopetition:

- dominated by cooperation,

- dominated by competition,

- where the level of cooperation and competition is the same.

According to the network approach, the company chooses one of the four relationships depending on two variables. The types of relationships in this approach include coopetition, competition, cooperation and coexistence, while the two variables are the relative position in the sector and the demand for external resources (Table 1).

Table 1.

Relations between competitors

\begin{tabular}{|l|l|l|l|}
\cline { 3 - 3 } \multicolumn{2}{c|}{} & \multicolumn{2}{|l|}{ Relative position in the sector } \\
\cline { 3 - 4 } \multicolumn{2}{c|}{} & strong & weak \\
\hline $\begin{array}{l}\text { Demand for internal } \\
\text { resources }\end{array}$ & strong & coopetition & cooperation \\
\cline { 2 - 4 } & poor & competition & coexistence \\
\hline
\end{tabular}

Source: (Bengtsson, and Kock, 2000).

Coopetition is multidimensional and multifaceted, takes different forms and occurs at different levels in the hierarchy of economic systems (Table 2).

Table 2.

Coopetition types depending on the level of analysis

\begin{tabular}{|l|l|}
\hline Analytical level & Coopetitors \\
\hline Global & National economies, integration groups \\
\hline Macroeconomic & Clusters, industries, economic sectors \\
\hline Mesoeconomic & Industry companies, cluster entities \\
\hline Microeconomic & Functional departments in companies, branches, strategic organizational units \\
\hline Micro-micro & Company employees \\
\hline
\end{tabular}

Source: (Jankowska, 2009).

The coopetitive links can be found in particular in the following sectors: ICT, biotechnology, pharmaceuticals and automotive, i.e. in sectors with a high level of knowledge (Jankowska, 2009). Among the industries in which coopetition plays an important role, the tourism industry should also be mentioned. The main argument in favor of this example is the complexity of the tourism product, which is the result of the links between numerous sectors of the economy. 


\section{Selected types of coopetittion in the development of agritourism business entities}

In the study directed at agrotourism business entities, located in Świętokrzyskie voivodeship, an interview questionnaire was used. A deliberate selection of the research area and the subjects surveyed was assumed. The research sample amounted to 150 agrotourism entities, which constitutes about $30 \%$ of all this type of entities operating in Świętokrzyskie voivodeship. The study was of a pilot nature and took place in November 2019.

The study used the approach developed by A.A. Lado, N.G. Boyd and S.C. Hanlon (Lado, Boyd, and Hanlan, 1997), who present various models of coopetition without using the term "coopetition". In their paper they focus on searching for profits in choosing the right strategic orientation. Implying the above approach, which is based on both competitive and cooperative approaches, four types of profit-seeking behavior can be distinguished (Table 3 ).

Table 3.

Types of coopetition

\begin{tabular}{|l|l|l|l|}
\cline { 3 - 4 } \multicolumn{2}{c|}{} & Cooperation \\
\cline { 3 - 4 } \multicolumn{2}{c|}{ Competition } & Low & High \\
\cline { 2 - 4 } & low & $\begin{array}{l}\text { Type 2 Contender } \\
17 \text { agrotourism business entities }\end{array}$ & $\begin{array}{l}\text { Type 1 Monoplayer } \\
\text { 63 agrotourism business entities }\end{array}$ \\
\cline { 2 - 4 } & & $\begin{array}{l}\text { Type 3 Partner } \\
\text { 22 agrotourism business entities }\end{array}$ \\
\hline
\end{tabular}

1. The monoplayer type is a farm that does not interact, maintaining both a low level of competition and cooperation.

2. The contender type is characterized by a high level of competition, while maintaining a low level of cooperation.

3. The partner type ensures a high level of cooperation, but low level of competition with other market players.

4. The adapter type is a farm with a high degree of cooperation and competition.

Source: Own elaboration based on (Lado, and Boyd, and Hanlan, 1997) and the study conducted.

Among the studied agrotourism business entities, the largest number of businesses (63) employs type 1, characterized by a low level of both competition and cooperation. These are entities whose owners implement their own market strategy, which they describe in the survey as "survival in the market". They have small agrotourism entities, regular customers and most often they are the one of only a few such entities in the commune. Type 4 includes entities of which there are at least several in the commune. Their owners form associations and work for the benefit of the local tourism market.

Some researchers tackling the problem, like M. Bengtsson and S. Kock (Bengtsson, and Kock, 2000), believe that competition between partners occurs closer to the customer, while cooperation in relations more distant from the customer. This is confirmed by results of own studies. The owners of agrotourism business entities stressed that they were competing for the customer, while within the associations to which they belonged they worked with their competitors for the so-called common good. At this point it should be added that there are 
17 agrotourism associations in Świętokrzyskie, associating nearly $60 \%$ of the 456 agrotourism business entities operating in the region.

Coopetition may be considered as a direction of links between entities. Depending on the direction, the following are distinguished: vertical links, horizontal links and mixed links. Among the respondents, 112 entities are linked in horizontal networks whose aim is to cooperate for the benefit of the local community in order to attract tourists, for example through activities promoting the region. Another 30 agrotourism business entities were linked in vertical networks, all of which produced organic food in addition to engaging in agrotourism. In these cases, the vertical links concerned sales of organic products and covered food suppliers and consumers. The remaining 8 of the studied entities were linked into mixed networks. In each case, they formed associations in horizontal links and vertical relationships in producer groups (organic food production). It should be added that the links were of a long-term nature (with $90 \%$ of respondents they lasted for over two years) and concerned formal (75\%) and informal ( $25 \%$ of respondents) relationships.

\section{Reasons for the implementation of the coopetition strategy in agrotourism business entities}

The results of the study show that the decision to implement a coopetition strategy was either opportunity-oriented or forced. This first reason concerns very few business entities. Their activities are entrepreneurial in nature and result from the desire to realize own ambitions or to exploit a market gap. The owners of 27 entities are local leaders and were behind the formation of local associations or foundations. Such cooperation facilitates the promotion of services, exchange of experience, maintenance of folklore, cultural and culinary traditions. Cooperative relations are in these cases created to achieve specific objectives, within a specific time horizon and their consequences have a significant impact on the development strategy of the entities involved.

However, the main reasons for adopting a strategy combining two opposing strategic behaviors are forced. The essence of these are actions taken out of necessity, e.g. for the purpose of gaining additional income or lack of satisfaction with the current economic situation. Owners of 123 entities stressed that their coopetitive activities are carried out in order to increase the competitiveness of their business. According to these respondents, the combination of the key competences of several agrotourism entities makes the tourist offer in a given area more attractive. It is truly a unique proposal. The reason for combining key competences, emphasized by the respondents, is primarily to survive on the market, and as a lower priority to gain access to scarce resources or to gain a competitive advantage, impossible to achieve when working alone. 
Distinguishing skills as sources of competitive advantage or the importance of identifying and developing their key competences are mentioned in the literature (Czakon, 2005). The importance of coordination of cooperative activities in order to achieve the assumed objectives is emphasized. Hence, where there are local leaders or active agrotourism associations, the key competencies enable the achievement of a competitive advantage by means of: reducing transaction costs, costs of drafting agreements, negotiating with contractors or local authorities, etc. Regardless of the motivation behind the cooperative activities, thanks to cooperation itself, each party brings its assets into the agreement, and due to their combination, all parties can benefit from the synergy effect. The synergy effects achieved in a coopetition indicate the advantages of joint action, expressed in terms of better outcomes, both for the whole cooperative group and for its individual members. Increased efficiency is expressed not only by increasing the output yields, but also by reducing costs. The cooperation brings the desired synergy effect only if the right conditions are met: selection of cooperating parties, ensuring that the parties have adequate parity of responsibility and benefits in terms of decision-making and a proportionate division of tasks and their proper coordination.

\section{Advantages and disadvantages of undertaking coopetitions in the surveyed agrotourism business entities}

Among the most important advantages of the coopetition, the authors (Jankowska, 2009; Romaniuk, 2012; Gnywali, and Madhavan, 2006) list: mutual learning and stimulation of innovation, reduction of transaction costs, achievement of benefits of specialization (synergy), increase in company value, access to resources, strengthening the position of the company in relation to competitors which are not parties to the coopetition agreement, making fuller use of market opportunities, expanding the scale of operations, access to new markets. Table 4 presents the advantages of the coopetition according to the surveyed owners of agrotourism business entities.

Table 4.

Advantages of coopetition according to the respondents

\begin{tabular}{|l|l|}
\hline \multicolumn{1}{|c|}{ Advantages of coopetition } & $\begin{array}{l}\text { Number of indications (max. three could } \\
\text { be indicated) }\end{array}$ \\
\hline expanding the scale of operations & 280 \\
\hline $\begin{array}{l}\text { strengthening the position of the company in relation to } \\
\text { competitors which are not parties to the coopetition agreement }\end{array}$ & 211 \\
\hline access to new markets & 199 \\
\hline access to resources & 195 \\
\hline making fuller use of market opportunities & 105 \\
\hline reduction of transaction costs & 98 \\
\hline mutual learning and stimulating innovation & 88 \\
\hline increase in the company's value & 67 \\
\hline synergy effect & 60 \\
\hline
\end{tabular}

Source: based on own research. 
Among the three most important advantages, the respondents pointed to the expansion of the scale of operations, strengthening of the position of the company in relation to competitors which are not parties to the coopetition agreement and access to new customer markets. It should be noted that the length of cooperation is a factor strengthening the positive effects of coopetition. The respondents stressed that the longer the cooperation lasts, the greater its benefits. Another strengthening factor turns out to be trust, which, however, is difficult to build in a situation where business entities continue to compete despite the cooperation. For this reason, time, which verifies the cooperation, plays an important role and very often, as a result of the variability of the environment, encourages the transition from an individual to a collective approach. As K. Romaniuk (Romaniuk, 2012) stresses, an important factor favoring coopetition is making all cooperating and competing stakeholders aware that the success of one of them remains in strong interaction with the success of the other coopetitors. Selected factors stimulating coopetition may also constitute numerous barriers limiting the development of this phenomenon. An excellent example of such a factor can be the transfer of knowledge, which has a negative impact on its originator in particular (Loebecke, and Van Fenema, and Powell, 1999). Moreover, the coopetitor may use the acquired knowledge outside the framework of the agreement concluded between the partners - provided that the coopetition is of a formal nature.

In addition to the advantages of the coopetition strategy, there are also disadvantages, which include (Zakrzewska-Bielawska, 2013): the risk of leaks of knowledge and know-how from the company, which may result in a loss of control over the technology, opportunistic behavior of coopetitors, conflicts between competitors, crippling cooperation, investment in specific resources, i.e. those that are not typical of the company and will be used only for this cooperation, but require investment, loss of the possibility of cooperation with other entities due to an exclusivity clause, asymmetry of the arrangement, which may result from errors in establishing cooperative relations or occur during the course of the relationship, and which may turn into a loss of organizational and decision-making independence as a result of the actions of a stronger partner, low efficiency of jointly implemented processes and objectives, weakening of the market position and image of the company.

Among the three significant drawbacks of coopetitive activities, the respondents distinguished low effectiveness of jointly implemented processes and goals, conflicts between competitors, and so-called "group thinking", which limits independence and, as the respondents add, entrepreneurship in activities for the benefit of their business entity (Table 5). 
Table 5.

Disadvantages of the coopetition according to the respondents

\begin{tabular}{|l|l|}
\hline \multicolumn{1}{|c|}{ Disadvantages of coopetition } & $\begin{array}{l}\text { Number of indications (max. } \\
\text { three could be indicated) }\end{array}$ \\
\hline low efficiency of jointly implemented processes and objectives & 206 \\
\hline conflicts between competitors & 172 \\
\hline so-called "group thinking" & 122 \\
\hline opportunistic behavior of coopetitors & 98 \\
\hline weakening the market position and the company image & 79 \\
\hline $\begin{array}{l}\text { investments in specific resources, i.e. those that are not typical of the } \\
\text { company, will be used only for this cooperation and required investment }\end{array}$ & 65 \\
\hline
\end{tabular}

Source: based on own research.

According to B. Jankowska (Jankowska, 2009), too cooperative attitudes may lead to the so-called group thinking, which will limit the creation of new ideas and as a result in stagnation. Trust is crucial in coopetitive relations (Gąsiorowska-Mącznik, Piotrowska-Piątek, and Witczak-Roszkowska, 2019). Its low level often implies conflicts between the entities, which in small towns where agrotourism business entities operate is quite frequent.

What is conducive to building lasting coopetitive relationships is the conviction that the business entity will not be able to satisfy the rapidly changing needs of customers on its own. Another element conducive to the sustainability of links can also be the finding of common objectives, primarily strategic ones, by all partners. On the other hand, the threats to the durability of coopetition are seen mainly in: changes in the market size, development of new technologies and changes in preferences of competitors (Jankowska, 2009).

\section{Research perspectives of coopetition}

So far, research on coopetition has been conducted on a fragmentary basis. It should be noted that the majority of researchers consider coopetition to be a domain of strategic management (Czakon, 2005; 2009; Cygler, and Romanowska, 2014). The behavior of enterprises within the coopetitive relation is most often interpreted using three theoretical concepts, namely (Cygler, 2009):

- game theory; a non-zero-sum game where the added value is greater for a network of links than for individual players,

- theory of transaction costs: high costs of hierarchical structures and market transaction costs positively influence the willingness to undertake cooperation activities,

- resource theory; through cooperation partners gain resources that they are not able to generate separately.

A. Zakrzewska-Bielawska (Zakrzewska-Bielawska, 2013) reviewed different research perspectives in the field of cooperation (Table 6). 
Table 6.

Research perspectives of coopetition

\begin{tabular}{|l|l|}
\hline No. & Issues \\
\hline 1. & A look from the perspective of game theory, PARTS model, coopetition as a positive sum game. \\
\hline 2. & Behavioral perspective, cooperation as a search for economic rent, syncretic forms of rent appropriation. \\
\hline 3. & Incomplete congruence of interests and goals, change of perspective. \\
\hline 4. & $\begin{array}{l}\text { Resource perspective, knowledge-based advantage, coopetition as a value created by combining } \\
\text { knowledge with other players. }\end{array}$ \\
\hline 5. & Cooperative partnership as a response to opportunities and threats in the environment. \\
\hline 6. & Strategic management perspective. Coopetition as one of the competitive activities. \\
\hline 7. & $\begin{array}{l}\text { Microeconomic perspective, cooperation as a success factor for small and medium enterprises from the } \\
\text { e-business sector. }\end{array}$ \\
\hline 8. & $\begin{array}{l}\text { Global perspective, coopetition as a loosely connected system in which actors maintain a certain } \\
\text { interdependence without losing their organizational identity; domination of competition or cooperation } \\
\text { in a cooperative relation. }\end{array}$ \\
\hline 9. & $\begin{array}{l}\text { The resource and network perspective and the asymmetry of resources in cooperative networks result } \\
\text { from structural differences in position (advantages and disadvantages of specific positions in coopetitive } \\
\text { networks) and lead to differences in the scope and diversity of competitive activities of coopetitors. }\end{array}$ \\
\hline 10. & Dynamics theory, coopetition as a dialectical perspective of balance between opposing forces. \\
\hline 11. & $\begin{array}{l}\text { Inter-organizational dynamics, cooperation as a dynamic process, leading to the interweaving of } \\
\text { maximization and appropriation of the earned rent. }\end{array}$ \\
\hline 12. & $\begin{array}{l}\text { Coopetition from the perspective of learning strategies, mutual learning, symmetric learning and } \\
\text { disadvantageous asymmetric learning. }\end{array}$ \\
\hline 13. & $\begin{array}{l}\text { The perspective of the network and inter-organizational dynamics, coopetition as a process of value } \\
\text { creation and appropriation. }\end{array}$ \\
\hline 14. & Sectoral and corporate factors of coopetition. \\
\hline 15. & Network perspective, autonomy and dependence in coopetitive systems. \\
\hline 16. & Cluster perspective, coopetition in creative clusters. \\
\hline 17. & Coopetitive partnership in the case of small and medium-sized enterprises \\
\hline Souree \\
(Zakrewsa-Bielawsa, 2013$).$
\end{tabular}

Source: (Zakrzewska-Bielawska, 2013).

The research carried out by W. Czakon shows that the works devoted to coopetition are most often of a theoretical nature (Czakon, 2009). Research is carried out at various levels (macro, meso, micro) to present the effects of the coopetition. It turns out that a company's excellent product and resource equipment cannot provide a lasting advantage over its rivals. Competitive skills are also not enough. It becomes necessary to combine them with coopetition. If we consider the results of the coopetition from the point of view of its economic benefits, it can be concluded that it stimulates transfer of knowledge, market growth and technological progress. The relationship between the coopetition and a company's success has been the subject of numerous studies, which show that there is a positive relationship between the degree of cooperation with a market competitor and a company's success. The success of a company can be assessed using the following measures of value creation (Jankowska, 2009):

- efficiency, which means reducing transaction costs;

- complementarity identified with the value the company achieves through access to complementary material and technological resources as well as through the mutual complementarity of activities;

- the value of continuing relationships and agreements with given entities, which is reflected in the cost of switching;

- innovativeness, i.e. the value of introducing innovations in business. 
Based on the theses of the resource theory, it can be concluded that coopetition provides access to unique and necessary resources, including knowledge, relationships and networks, without depriving a company of the beneficial influence of competitive pressure. This pressure is useful from the perspective of generation of innovations. A company gets a chance to focus on its main area of activity, learning from its business partner. At the same time, since it is still in competition, it can continuously improve its competitive potential, based on its own experience. A company's membership in a certain social network is a valuable resource for it, and it also indicates that the coopetition results in the development trust and mutual positive engagement of companies in their businesses (Jankowska, 2009). Empirical studies published in the field of coopetition show a connection between the concept under study with innovation, market share growth and financial results.

Coopetition needs to be studied in depth in both theoretical and practical aspects. The last decade's tendency to establish cluster structures is conducive to undertaking research in this area. It therefore seems that this will be a convenient subject for analyzing and interpreting the coopetitive arrangements, which primarily occur in cluster structures, but which nowadays often operate in an informal way or take, in the tourism and agrotourism economy for example, the form of local organizations operating in areas that are attractive to tourists.

The previous research (Cygler, 2009) based on cluster analysis of coopetition show that one of the most important objectives of cooperation between entities of the cluster is the possibility of developing a common product or new technology. Most often, the transfer of innovation between cluster members takes place by means of the simplest tools and channels of imitation of behavior, through the exchange of information in the form of informal and formal meetings, but most of all, clusters operating in highly innovative industries have, thanks to cooperation with research and development units, adequate facilities for creating common innovative solutions (Benchmarking klastrów w Polsce, 2018). The exchange of knowledge and experience mainly concerns the technologies used, areas of possible cooperation, knowledge of legal solutions used in a given industry, organizational matters, possibilities of financing joint projects or implementation thereof, possibilities of lending production equipment, etc. In the case of coopetitors operating within a cluster structure, particular material, financial and human resources are not owned by a single entity, therefore a single entity cannot use a given resource without the agreement of partners. The synergy effect of functioning within a cluster is impossible to achieve without the involvement of all parties, who make their resources available for both individual and collective gain. In this way, relatively durable competitive advantages that are difficult for competitors to imitate are gained, which are conducive, among other things, to joint problem-solving or mutual learning. The process of coordinating the decisions, attitudes and behaviors of individual partners makes them start working to achieve common strategic goals over time, and of course, work to achieve individual goals of their own organizations as well. 
Although the concept of coopetition is present in the literature on strategic and economic management, there is still a lack of research and empirical analysis of the phenomenon. The combination of two contradictory relations gives a completely new perspective on inter-organizational links. A new strategy is emerging which, in addition to classic activities such as competition, searching for a market niche or avoiding any type of competition, is becoming increasingly applicable in economic practice.

\section{Summary}

Coopetition is not a typical cooperation relationship. It is distinguished by two important characteristics (Czakon, 2009). First of them is the simultaneity of occurrence of competitive and cooperative behaviors as the basic inter-organizational relations. The second characteristic of a coopetition is mutual benefit or added value for the entities participating in the coopetition.

The analysis of the results of the pilot studies shows that the coopetition strategy is more beneficial for agrotourism business entities than competition and cooperation strategies implemented separately. The research shows that coopetitive relations are of a well-thought out, long-term and formal nature. The main motivation behind them is to increase competitiveness on the market. When making a decision on cooperation, the surveyed owners of agrotourism business entities most often treat it as a strategic decision, i.e. relating to effects in a distant time horizon. The respondents see the benefits of coopetition such as: the expansion of the scale of operations, strengthening of the position of the company in relation to competitors which are not parties to the coopetition agreement and access to new customer markets. The following correlation occurs: the longer the cooperation of coopetitors lasts, the greater its benefits. Trust turns out to be a factor strengthening the relations, which, however, is difficult to build in a situation where companies continue to compete despite the cooperation. For this reason, the time that verifies the undertaken cooperation effort is of significance. The surveyed owners of agrotourism business entities are also aware of the risks of coopetition activities, and among many, the most important are: low effectiveness of jointly implemented processes and objectives, conflicts between competitors and the so-called "group thinking", which limits independence and, as the respondents add, entrepreneurship in activities for their business entity. Coopetition, by combining two opposing strategies, creates a completely new strategic bond between agrotourism business entities, playing, on the one hand, a big role in building their competitive advantage and, on the other hand, creating and strengthening relations between various entities operating on the local market. 
The research carried out was of a pilot nature. The planned future research will cover agrotourism business entities throughout the country. An important direction of research, due to its nationwide dimension, will be to determine the spatial differences in the implementation of the coopetition strategy, as well as the conditions of the identified differences.

\section{References}

1. Benchmarking klastrów w Polsce - 2018, Available online https://www.parp.gov.pl/ storage/publications/pdf/20190128150014m9kdr.pdf, 30.05.2020.

2. Bengtsson, M., Kock S. (2000). Coopetition in business networks to cooperate and compete simultaneously. Industrial Marketing Management, No. 29, pp. 411-426.

3. Brandenburger, A.M., Nalebuff B.J. (1996). Co-Opetition: A Revolution Mindset That Combines Competition and Cooperation: The Game Theory Strategy That's Changing the Game of Business. Harper Collins Business, No. 47(1), pp.57-71.

4. Cygler, J. (2009). Kooperencja przedsiębiorstw. Czynniki sektorowe i korporacyjne. Warszawa: Oficyna Wydawnicza SGH, p. 19.

5. Cygler, J., Romanowska, M. (2014). Granice zarzadzania. Warszawa: Oficyna Wydawnicza SGH, p. 204.

6. Czakon, W. (2005). Ku systemowej teorii przewagi, konkurencyjnej przedsiębiorstwa. Przegląd Organizacji, No. 5, pp. 5-8.

7. Czakon, W. (2009). Koopetycja - splot tworzenia i zawłaszczania wartości. Przeglad Organizacji, No. 12, pp. 11-14.

8. Gąsiorowska-Mącznik, E., Piotrowska-Piątek, A., Witczak-Roszkowska, D. (2019). Kształtowanie relacji międzyorganizacyjnych. Kielce: Wydawnictwo Politechniki Świętokrzyskiej, pp. 19-43.

9. Gnywali, D., He, J., Madhavan, R. (2006). Impact of co-opetition on firm competitive behavior: an empirical examination. Journal of Management, Vol. 32, No. 4, p. 31.

10. Jankowska, B. (2009). Konkurencja czy kooperacja. Ekonomista, No. 1, pp. 67-89.

11. Lado, A.A., Boyd, N.G., Hanlan, S.C. (1997). Competition, Cooperatiom and the Search for Economic Rents: A Syncretic Model. Academy of Management Review, No. 1, pp.110141.

12. Loebecke, C., Van Fenema, P.C., Powell, P. (1999). Co-opetition and Knowledge Transfer. The DATA BASE for Advances in Information System, No. 30, pp. 14-25.

13. Romaniuk, K. (2012). Koopetycja przedsiębiorstw - nowa perspektywa strategiczna. Współczesne zarządzanie, No. 4, pp. 65-71. 
14. Stańczyk-Hugiet, E. (2011). Koopetycja, czyli dokąd zmierza konkurencja. Przegląd Organizacji, No. 5, pp. 8-12.

15. Zakrzewska-Bielawska, A. Koopetycja - strategia sukcesu? Doświadczenia przedsiębiorstw high-tech. Retrieved from http://zif.wzr.pl/pim/2013_4_1_32.pdf, 25.05.2020. 